S. G. OUEllet,* A. ROY, C. MOlinARO, R. ANGElaud, J.-F. MARCOUX, P. D. O'SheA,

\title{
Synthesis of the Biaryl Core of Anacetrapib
}<smiles>Fc1ccc(Br)c(F)c1</smiles>

A

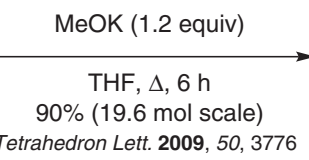

Tetrahedron Lett. 2009, 50, 3776<smiles>COc1cc(F)ccc1Br</smiles>

B

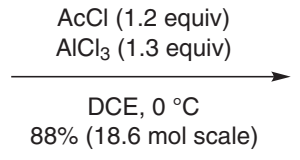

$88 \%(18.6 \mathrm{~mol}$ scale $)$ mp not reported

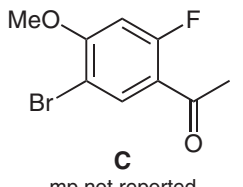

$\mathrm{MeMgCl}$ (2.0 equiv) THF, $0{ }^{\circ} \mathrm{C}, 4.5 \mathrm{~h}$<smiles>COc1cc(F)c(C(C)C)cc1C1=NCCO1</smiles>

G mp not reported

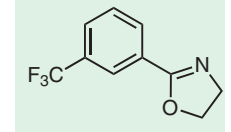

$\mathbf{F}$ (1.1 equiv)

$\mathrm{RuCl}_{2}(\mathrm{PhH})_{2}(1 \mathrm{~mol} \%)$ $\mathrm{Ph}_{3} \mathrm{P}(2 \mathrm{~mol} \%)$ AcOK (10 mol\%)

$\mathrm{K}_{3} \mathrm{PO}_{4}$ (2 equiv) NMP, $120^{\circ} \mathrm{C}, 9 \mathrm{~h}$
E<smiles>COc1cc(F)c(C(C)C)cc1Br</smiles>
$94 \%(16.65 \mathrm{~mol}$ scale $)$

$\left(\mathrm{HSiMe}_{2} \mathrm{O}\right)_{2} \mathrm{O}$ (1.0 equiv) $\mathrm{Me}$ TFA (1.3 equiv)

DCE, $-10^{\circ} \mathrm{C}$ $88 \%$ (15.5 mol scale)<smiles>COc1cc(F)c(C(C)(C)O)cc1Br</smiles>
D mp not reported
Synthesis of Natura

Products and

Potential Drugs

\section{Key words}

anacetrapib

rutheniumcatalyzed direct

arylation

regioselective $S_{N} A r$ reaction

reductive dehydration

$$
\begin{array}{l|l}
96 \%(11.4 \text { mol scale }) \\
10.15 \text { mol scale } \\
\mathrm{CICO}_{2} \mathrm{Me}(1.2 \text { equiv }) \\
\operatorname{DIPEA}(0.1 \text { equiv) } \\
\operatorname{THF}, 62{ }^{\circ} \mathrm{C}, 45 \mathrm{~min}
\end{array}
$$<smiles>COC(=O)N(CCCl)C(=O)c1cc(C(F)(F)F)ccc1-c1cc(C(C)C)c(F)cc1OC</smiles>

H

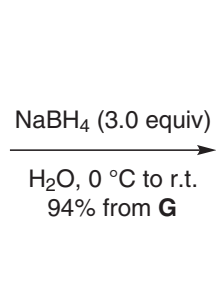

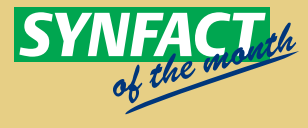

Significance: Anacetrapib inhibits cholesteryl ester transfer protein (CETP), a plasma glycoprotein that transfers cholesteryl ester from high density lipoprotein to low density lipoprotein and very low density lipoprotein, consequently lowering the risk of atherosclerosis. Key steps in the synthesis depicted are (1) a highly regioselective $S_{N} A r$ reaction of 1-bromo-2,4-fluorobenzene (A) with potassium methoxide ( $r r=17: 1)$ and (2) a multi-kilogram scale ruthenium-catalyzed direct arylation of oxazoline $\mathbf{F}$ to construct the biaryl $\mathbf{G}$.
Comment: The Merck workers noted a significant difference in the reaction efficiency and robustness of the ruthenium-catalyzed direct arylation reactions, which was a consequence of low levels of $\gamma$-butyrolactone contamination of the NMP. This fortuitous discovery led to the use of potassium acetate as an additive that allowed the reduction of catalyst loading while maintaining reproducibly high yields. 